\title{
XVII. Propositions respecting the mechanical power of the wedge
}

\author{
Mr. Peter Nicholson
}

To cite this article: Mr. Peter Nicholson (1798) XVII. Propositions respecting the mechanical power of the wedge, Philosophical Magazine Series 1, 1:3, 316-319, DOI: $10.1080 / 14786449808676843$

To link to this article: http://dx.doi.org/10.1080/14786449808676843

曲 Published online: 04 Mar 2010.

Submit your article to this journal $₫$

Џ Article views: 3

Q View related articles $\square$ 
dence fhall be put into practice, thofe, and many more than 1 can think of at prefent, will of themfelves occur; fo that I do not in the leaft doubt, but that with a little practice, all things may be made fo convenient, that the fame character may be feen at Paris within a minute after it hath been expofed at London; and that the characters may be expofed fo quick after one another, that a compofer fhall not much exceed the expofer in fwiftnefs; and this not only at the diftance of one ftation, but of a hundred; for, fuppofing all things ready at all thofe feveral ftations for obferving and expofing, as fatt as the fecond obferver doth read the characters of the firf expofer, the fecond expofer will difplay them to the obferver of the third ftation, whofe expofer will likevife difplay them for the fourth obferver, as fat as his obferver doth name them to him, or write them down.

" There may be many objections brought againft this way of communication, becaufe it has not yet been put in practice; but hardly any that may not be eafily anfwered and obviated." Dr. Hook illuftrates his invention thus :

"Let A B C (Plate X. fig. 4.) reprefent three very long matts or poles erected; E, the top-piece, that joins them all together; D, a fcreen, belsind which all the deal-board characters hang upon certain rods or lines, and may, by the help of fmall lines connected with each of them, be expofed at $F$, or drawn back again behind $D$, as occafion thall require."

XVII. Profofitions refpecting the Mechanical Power of the Wedge, by Mr. Peter Nicholson of Newman-ftret. Communicated by the Autbor.

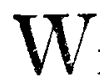

RITERS on mechanics, in treating of the wedge, have frequently drawn falfe conclufions refpecting the proportion which exifts between the impelling power applied to the head, and the refifting powers oppofed to the fides; and 
thofe conclufions have refulted from falfe opinions concerning the directions of the refiting powers.

It is evident, that when wood or other fubftance is fpilt by a wedge which does not fill the cleft, that is, when the angle of the cleft is more acute than that of the wedge, the power or action of each fide of the wedge, equal and oppofite to the refiftance of the cleft, muft be refolved into two; the one in the direcion of the fide of the cleft, which tends to thruft it forward; and the other perpendicular to that direction, which tends to tear it alunder. It is by not attending to the above refolution that writers on this fubject have been led into miftakes ; for, inftead of confidering the powers which act in thofe two directions, they have imagined a fingle power only as acting obliquely on each fide. But if the fides of the wedge are perfectly polifhed, as we muft here confider them, no fingle permanent power can be applied to impel any one of them, unlefs its direction be perpendicular to the plane of the fide to which it is applied : therefore two oblique powers, applied on oppofite fides of the fame point, are at leaft neceffary to fuftain each other and the action of the plane; and in the cale of the wedge above mentioned, the directions of thofe two oblique powers will always be perpendicular to each other, as will appear obvious from the two following propofitions:

Prop. I, Let A B C (Fig. 3, Plate X.) be a verrical fection paffing through the centre and at right angles to the head and fides of any iforceles wedge; alio in the plane of this fection, and at right angles to its fides $\mathrm{A} \mathrm{C}, \mathrm{B} \mathrm{C}$, and C A, let three powers be applied, fuch, that their directions may all mutually interfect in the axis, and their efforts fuftain the wedge in equilibrio; I fay, that thefe three powers are as $\mathrm{AB}, \mathrm{BC}$, and $\mathrm{C} A$ refpectively.

Let L M, KI, ED be the directions of thefe three powers, which produced, interfect each other aud the axis in $O$. Since, by hypothefis, thefe thrce powers directed to the fame point are in equilibrio, and the three fides of the triangle $A B C$ are at right angles to their circotions; therefore, by a 
well known fatical principle, the intenfities of thefe powers are as $\mathrm{AB}, \mathrm{BC}$, and $\mathrm{C} \mathrm{A}$ refpectively.

Prop. II. When an impelling power applied to the head of an ifofceles wedge is in cquilibrio with the refifing power of a cleft, the angle of which is more acute than that of the wedge inferted, then univerfally,

The impelling power applied to the head,

The action of the wedge on either fide of the cleft,

The part thereof which tends to thruft it forward,

And the remaining part, which tends to tear it afunder, Are

As twice the fine of half the vertical angle of the wedge, The radius,

The fine of the angle contained by the fides of the wedge and cleft,

And the co-fine of that angle refpectively, the fame radius being common.

Let Fig. 2, Plate $\mathrm{X}$. reprefent a vertical fection of the wedge and cleft, fimilar in pofition to that defcribed in Propofition I; allo let the two fides of the cleft $\mathrm{DH}, \mathrm{DH}$ be equal, and in contact with the fides of the wedge A C, A C at equal diftances $\mathrm{DC}, \mathrm{DC}$ from the vertex $\mathrm{C}$, in which cafe the fides of the wedge make equal angles with thofe of the cleft. 'Through either point $D$, draw DF at right angles, and equal to $\mathrm{A} C$; alfo through $\mathrm{D}$, draw $\mathrm{DE}$, at right angles to $\mathrm{DH}$, and complete the parallelogram DEFG. Then by Propofition I, the line AA reprefents in quantity the impel. ling power applied to the head, and the line D F reprefents in quantity and direction the whole action of the fide of the wedge on that of the cleft, which by hypothefis is balanced by its refiftance; but the power $D F$ is refolved into two, reprefented in quantity and direction by $\mathrm{DG}, \mathrm{DE}$ repectively: the one, being in the direction of the cleft, tends to thruft it forward; and the other, being at right angles thereto, tends to tear it afunder.

Therefore the powers mentioned in the Propofition are as $A \mathrm{~A}, \mathrm{DF}, \mathrm{DG}$ and $\mathrm{DE}$ refpectively; but $\mathrm{AC}=\mathrm{DF}$ being radius, thefe lines are refpectively equal to 
Twice the fine of half the vertical angle of the wedige,

The radius,

The fine of the angle contained by the fides of the wedge and cleft,

And the co-fine of that angle. Fence the propofition is manifeft.

XVIII. Report of the Commiffoners appointed by the National Inftitute to repeat the Experiments wbicb bave been made on Galvanifm: read in the Name of tbe Commifion by Cit. Halle. From the Bulletin des Sciences, par la Société Philomathique, Thermidor, An VI.

$\mathrm{T}$ HE commifion was not fatisfied with repeating a great part of the experiments already made : they claffed them, and rendered them complete by the addition of others which were wanting.

I. The phenomenon of Galvaniftr, taken in general, is as follows : A communication is eftablifhed between two points of a feries of nervous or mufcular organs by means of certain determined fubftances. At the moment when this commu . nication is macle, there take place in the ftate of the organs changes, the nature of which is ftill unknown; but which are manifefted by fenfations more or lefs lively, or contractions more or lefs violent. Thefe mufcular contractions take place even in feparated parts of the body, and with as much force as when produced by the moft effectual means of irritation. The feries of mufcular or nervous organs is called the animal arc; the other fubftances form the exciting arc. The conprofition of both may be varied many different ways.

II. Among the effeets refulting from the different compofitions of the animal arc, the following are the moft remarkable: A ligature made on a nerve does not intercept Galvanifm, unlefs it be made in the part furrounded with fleh. If the 